\title{
Morphology and features of Cambrian oncoids and responses to palaeogeography of the North China Platform
}

\author{
En-Zhao Xiao ${ }^{1^{*}}$ (D, Ming-Xiang Mei ${ }^{1}$, Shu Jiang ${ }^{2}$ and Tehseen Zafar ${ }^{3,4}$
}

\begin{abstract}
The Cambrian strata in the North China Platform are fully exposed. A wide variety of carbonate oncoids with different shapes occur in the Xuzhuang and Zhangxia formations (Miaolingian Series) from six Cambrian sections in the study area. A comprehensive study involving outcrop description, microscopic observation, scanning electron microscopy (SEM), energy dispersive X-ray spectroscopy (EDX), X-ray diffraction (XRD), and carbon and oxygen isotope analysis is conducted to determine the facies, morphology, internal structure, and geochemical properties of the oncoids. The oncoids are divided into six types based on their morphology and internal structure. Microscopic and ultrastructural observations reveal typical microbial fossils (Girvanella) and microbially-related sediments (framboidal pyrite), indicating the biogenicity of the oncoids. Additionally, the XRD and carbon and oxygen isotope analysis results suggest that the formational environments of these oncoids are different due to terrestrial influences. Statistical data on the oncoids from the six sections show that there are obvious differences in the types of oncoids and the proportions of different varieties in each section. The spatial differences in the oncoid morphologies are associated with different palaeogeographic settings. The rough oncoid growth patterns developed in nearshore environments were influenced by terrigenous debris and steep terrain, whereas the delicate oncoid growth patterns developed in offshore environments were less affected by terrestrial factors and were featured by more stable depositional processes related to microbial mats.
\end{abstract}

Keywords: Morphological classification, Microbial mat, Girvanella, Carbon and oxygen isotopes, Miaolingian series, North China

\section{Introduction}

As a significant type of carbonate grain, oncoids have attracted extensive attention from geologists for decades. Oncoids in the geological record are characterized as unattached, rounded, and $\mathrm{mm}$ - to $\mathrm{cm}$-sized and commonly exhibit a micritic cortex consisting of more or less concentric and partially overlapping laminae around a bio- or lithoclastic nucleus (Jones and Renaut 1997; Shapiro et al. 2009; Flügel and Munnecke 2010; Han et al. 2015; Wang and Xiao 2018). Studies of oncoids have revealed that clear understanding of the formation mechanism, classification and microbial metabolism recorded by exquisite internal structures (Zhang et al.

\footnotetext{
* Correspondence: xiaoenzhao@163.com

${ }^{1}$ School of Earth Sciences and Resources, China University of Geosciences (Beijing), Beijing 100083, China

Full list of author information is available at the end of the article
}

2013; Han et al. 2015; Wilmeth et al. 2015) can guide the reconstruction of palaeogeography and palaeoenvironments (Dahanayake 1977; Peryt 1983; Jones 1992, 2011; Jones and Renaut 1997, 2010; Gradziński et al. 2004; Védrine et al. 2007; Védrine 2008; Yang et al. 2009, 2011; Flügel and Munnecke 2010; Zhang et al. 2014a, 2014b, 2015; Wang and Xiao 2018). Previous studies usually noted that the oncoid nucleus is composed of biodetritus or carbonate debris (Peryt 1983; Tucker and Wright 1990; Riding 1991), which was captured and surrounded by calcareous particles during the growth processes of microorganisms or algal communities (Flügel and Munnecke 2010). In recent years, through further studies of potential biosignatures from geological records and microbial-mediated organomineralization, the discussion of oncoids, including definition, genesis, type characteristics, classification and positions 
within microbialites (Wang and Xiao 2018), has again become a major topic in sedimentology.

Cambrian oncoids have been reported in the southern and eastern margins of the North China Platform (Zhang et al. 2014a, 2014b), including western Henan Province (Zhang et al. 2015; Qi et al. 2016) and western Shandong Province of China. However, very few studies have examined the oncoids in the Cambrian Miaolingian Series that are exposed in the northern margin of the North China Platform in detail. Therefore, this study was conducted to provide an extensive range of reference materials for the latter. In total, 240 representative oncolitic limestone samples were collected from Wuhai, Diaoquan, Xiaweidian, Sandaogou, Fuzhou Bay, and Jinzhou Bay sections (Figs. 1, 2). The standard carbonate microfacies analysis shows morphological differentiation of oncoids in the study area. The study aims to demonstrate the origin of these oncoids and analyze possible factors that led to their morphological differentiation through comparative studies in a large region using sedimentological and geochemical methods.

\section{Materials and methods}

Field observations were conducted, involving measuring and sampling the Cambrian Miaolingian Series exposed in six sections in the North China Platform (Fig. 1). Stratigraphic successions were reconstructed based on field and laboratory studies. Two hundred fouty fresh, representative oncolitic limestone samples were collected from the Xuzhuang and Zhangxia formations, i.e.,

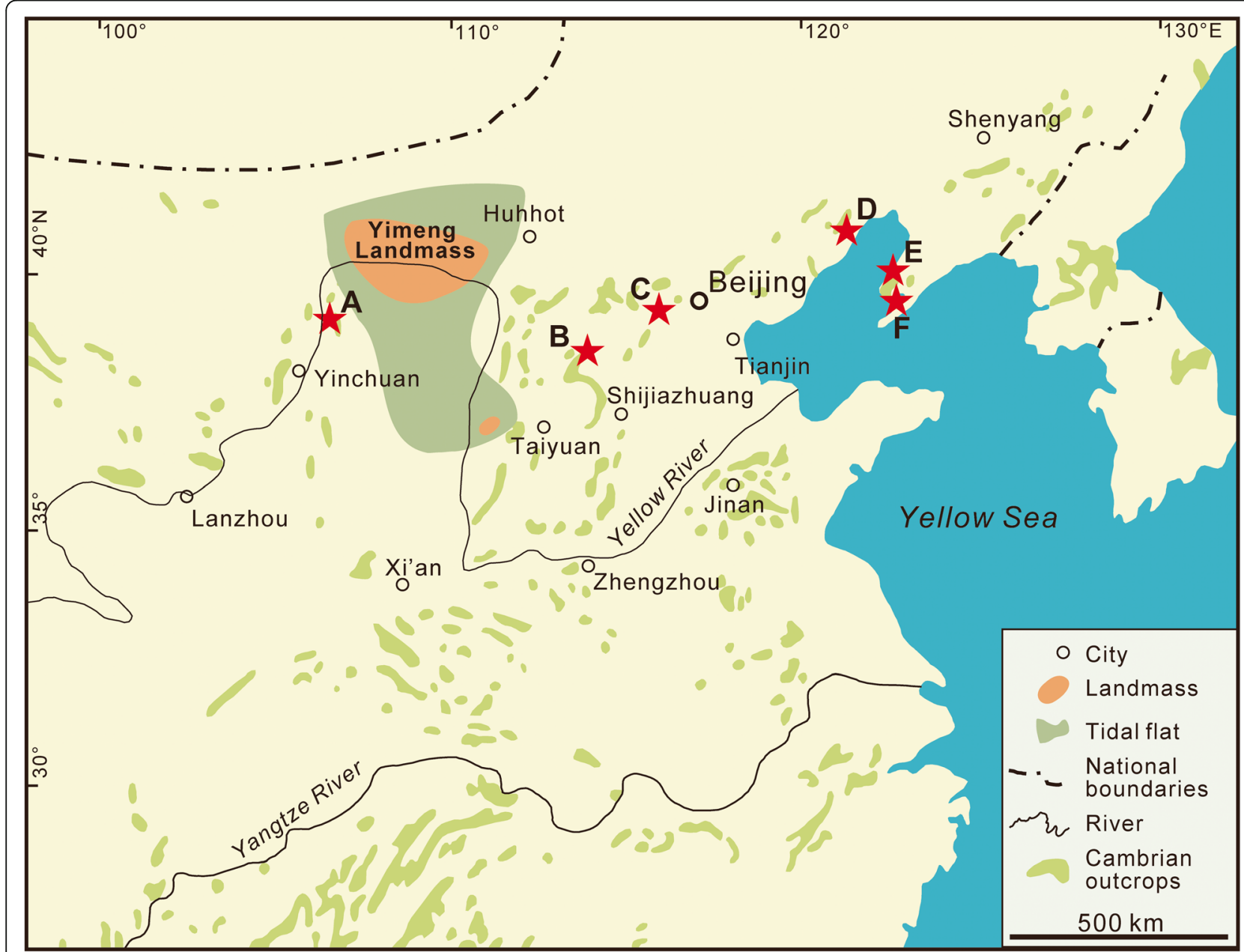

Fig. 1 Cambrian outcrops in the North China Platform and the locations of studied sections (red stars). A-Wuhai section: Gandel Mountain, Wuhai City, Inner Mongolia Autonomous Region, China; B-Diaoquan section: Diaoquan village, Lingqiu county, Datong City, Shanxi Province, China; C-Xiaweidian section: Xiaweidian village, Mentougou district, Beijing, China; D-Sandaogou section: Sandaogou village, Suizhong county, Huludao City, Liaoning Province, China; E-Fuzhou Bay section: Fuzhou Bay town, Jinzhou district, Dalian City, Liaoning Province, China; F-Jinzhou Bay section: Dalian City, Liaoning Province, China. Topographically, the western margin of Yimeng landmass was steeper than the eastern during the Cambrian, which means that the Cambrian successions in the Wuhai section is related to a deeper water environment than those of the other five sections (Feng 2004) 


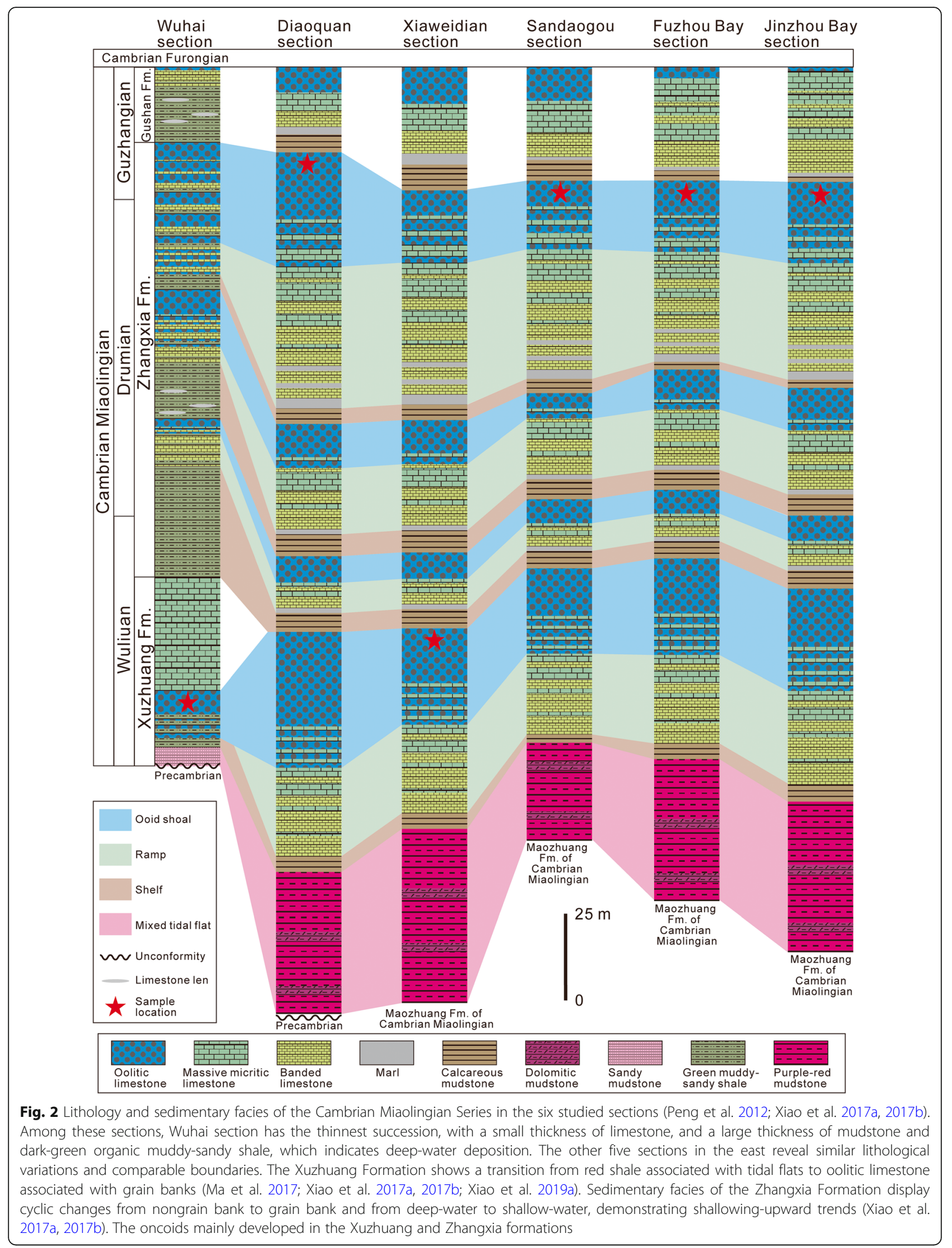


40 from each section. Microfacies observations of polished samples and thin sections (under crosspolarized light (XPL) and plane-polarized light (PPL)) were performed to identify the main lithological and biological components.

Among these samples, 10 from each section, i.e., a total of 60 samples were selected, and were prepared into 60 small cubes with fresh broken surfaces as well as 60 polished thin sections, which were observed under a FEI Quanta 200F scanning electron microscope (SEM). Meantime, the 60 polished thin sections were gold-coated for secondary electron imaging. Semiquantitative elemental analyses of submicronsized spots during SEM observations were attained through energy dispersive X-ray spectroscopy (EDX). The voltage of the EDX element analysis was $10.0 \mathrm{kV}$, and the current pulse ranged from $19.83 \mathrm{kcps}$ to 42.58 kcps.

Another 30 samples, i.e., 5 from each section, were microdrilled on their fresh surface to prepare microsamples for carbon and oxygen isotope analyses. The micro-sampling process was taken under a microscope to avoid calcite veins and neomorphic processes. Isotopic compositions $\left(\delta^{13} \mathrm{C}\right.$ and $\left.\delta^{18} \mathrm{O}\right)$ were measured by a Thermo Scientific Delta V Advantage continuous-flow isotope ratio mass spectrometer. The results are presented in delta $(\delta)$ notation relative to the Vienna Pee Dee Belemnite (VPDB) standard. In addition, the precision of the carbon and oxygen isotopic ratios for duplicate analyses was better than $0.1 \%$. The bulk mineral compositions of the samples were determined by XRD analyses, which were performed on prepared powder samples using the Bruker D2 PHASER instrument. All geochemical analyses of oncolitic limestone samples were performed in the State Key Laboratory of Oil and Gas Geology and Exploitation, Chengdu University of Technology, China.

A total of 200 oncoids from each section were randomly selected and observed under a microscope to identify oncoid types as well as their proportions in different sections.

\section{Results}

\subsection{Macroscopic characteristics of oncoids}

The studied oncoids mainly developed in shallow-water environments. They occur within oolitic limestones (Fig. 2), which range in thickness from approximately $0.3 \mathrm{~m}$ to $5 \mathrm{~m}$, and are composed of layered limestone interbedded with thin micritic limestone layers. The oncoids are ellipsoidal or elongated in shape, with the long axis approximately $0.3-2.3 \mathrm{~cm}$ long (Table 1; Fig. 3).

These oncoid-bearing beds are relatively thin, i.e., 0.3 $\mathrm{m}$ thick in the Wuhai section and $2.2 \mathrm{~m}$ thick in the
Diaoquan section, respectively. In contrast, they are much thicker in the other four sections, i.e., $3.75 \mathrm{~m}$ thick in the Xiaweidian section, $4.5 \mathrm{~m}$ thick in the Sandaogou section, $5.2 \mathrm{~m}$ thick in the Fuzhou Bay section, and $4.9 \mathrm{~m}$ thick in the Jinzhou Bay section, respectively (Table 1).

\subsection{Microscopic characteristics of oncoids}

Microscopic observation shows that the oncoids grow together with ooids in the studied sections. The individual oncoids are circular to subcircular in shape and vary in size. Most oncoids contain a nucleus, which is typically composed of dark micrite, trilobite debris or echinoderm debris. In addition, most oncoids are characterized by alternating light and dark laminae and can be thought of as spherical stromatolites (Logan et al. 1964). Petrographically, the light laminae are composed of microspar, while the dark laminae are composed of dark micrite. In addition, filamentous cyanobacterial fossils, particularly Girvanella, are observed in the cortex and inside the interior laminae of oncoids.

Based on the oncoid morphology, including the internal structure revealed by petrography, development of nucleus and laminae, location of nucleus, and other morphological features, the oncoids are divided into six varieties as follows: type 1, concentric fine-laminar oncoids; type 2, concentric rough-laminar oncoids; type 3, lateral-growth oncoids; type 4, multicore oncoids; type 5, flaggy oncoids; and type 6, thincortex oncoids.

\subsubsection{Type 1, concentric fine-laminar oncoids}

Concentricfine-laminar oncoids are the most common type of oncoids documented in geological records ( $\mathrm{Li}$ et al. 2000; Schaefer et al. 2001; Shi and Chen 2006; Reolid and Nieto 2010; Yang et al. 2011; Wang and Xiao 2018). Based on microscopic observations, this type is circular or elliptical in shape, with obvious nuclei and relatively smooth edges (Fig. 4a), and contains a large number of 50- $\mu \mathrm{m}$-thick concentric laminae, which are highly-distinct and in light-and-dark color. Additionally, filamentous microbial fossils are observed inside the dark laminae and between the light and dark laminae at a high magnification. They show typical features of Girvanella, i.e., a dark-micrite sheath and microspar interior (Fig. 4b) (Riding 2011; Xiao et al. 2018), which are intertwined with each other inside the oncoid laminae (Fig. 4b).

Except in the Wuhai and Diaoquan sections, type 1 oncoids are observed with a relatively large spatial distribution and make up a large proportion among all oncoid types in the Jinzhou Bay (73\%, 146 in 200), Fuzhou Bay (79\%, 158 in 200), Sandaogou (72\%, 144 in 200) and Xiaweidian $(56.5 \%, 113$ in 200$)$ sections. 
Table 1 Field observation characteristics of various oncoids in the Cambrian Miaolingian Series, North China Platform

\begin{tabular}{|c|c|c|c|c|}
\hline $\begin{array}{l}\text { Section } \\
\text { name }\end{array}$ & Strata & $\begin{array}{l}\text { Diameter of } \\
\text { oncoids }(\mathrm{cm})\end{array}$ & Facies & Field observation characteristics \\
\hline $\begin{array}{l}\text { Wuhai } \\
\text { section }\end{array}$ & $\begin{array}{l}\text { Middle } \\
\text { Xuzhuang } \\
\text { Formation }\end{array}$ & $0.3-1.2$ & $\begin{array}{l}\text { Ooid } \\
\text { shoal }\end{array}$ & $\begin{array}{l}\text { The thickness of oncoid-bearing oolitic limestone beds is about } 0.3 \mathrm{~m} \text {. There is no clear } \\
\text { boundary between oncoids and ooids. The individual oncoids have small diameters and } \\
\text { appear relatively dispersed. It is overlain by massive micrite limestone of the upper Xuz- } \\
\text { huang Formation, and underlain by green muddy-sandy shale interbedded with thin oo- } \\
\text { litic limestone of the lower Xuzhuang Formation. }\end{array}$ \\
\hline $\begin{array}{l}\text { Diaoquan } \\
\text { section }\end{array}$ & $\begin{array}{l}\text { Top Zhangxia } \\
\text { Formation }\end{array}$ & $0.9-2.1$ & $\begin{array}{l}\text { Ooid } \\
\text { shoal }\end{array}$ & $\begin{array}{l}\text { The thickness of oncoid-bearing oolitic limestone beds is about } 2.2 \mathrm{~m} \text {. There is no obvious } \\
\text { boundary between the oncoids and ooids. The individual oncoids have bigger diameters } \\
\text { than those in the Wuhai section and show local concentration. The limestone is overlain } \\
\text { by calcareous mudstone of the lower Gushan Formation and underlain by massive micritic } \\
\text { limestone interbedded with thin oolitic limestone. }\end{array}$ \\
\hline $\begin{array}{l}\text { Xiaweidian } \\
\text { section }\end{array}$ & $\begin{array}{l}\text { Top Xuzhuang } \\
\text { Formation }\end{array}$ & $0.8-1.7$ & $\begin{array}{l}\text { Ooid } \\
\text { shoal }\end{array}$ & $\begin{array}{l}\text { The thickness of oncoid-bearing oolitic limestone beds is about } 3.75 \mathrm{~m} \text {. The individual } \\
\text { oncoids have relatively big diameters and are locally concentrated. The limestone is over- } \\
\text { lain by calcareous mudstone of the lower Zhangxia Formation and underlain by massive } \\
\text { micritic limestone interbedded with thin oolitic limestone. }\end{array}$ \\
\hline $\begin{array}{l}\text { Sandaogou } \\
\text { section }\end{array}$ & $\begin{array}{l}\text { Top Zhangxia } \\
\text { Formation }\end{array}$ & $0.5-1.8$ & $\begin{array}{l}\text { Ooid } \\
\text { shoal }\end{array}$ & $\begin{array}{l}\text { The thickness of oncoid-bearing oolitic limestone beds is about } 4.5 \mathrm{~m} \text {. There is no clear } \\
\text { boundary between the oncoids and ooids. Vertically, individual oncoid sizes at the bottom } \\
\text { of the bed are small and gradually increase upwards. The limestone is overlain by calcar- } \\
\text { eous mudstone from the lower Gushan Formation and underlain by massive micritic lime- } \\
\text { stone interbedded with thin oolitic limestone. }\end{array}$ \\
\hline $\begin{array}{l}\text { Fuzhou Bay } \\
\text { section }\end{array}$ & $\begin{array}{l}\text { Top Zhangxia } \\
\text { Formation }\end{array}$ & $0.7-2.3$ & $\begin{array}{l}\text { Ooid } \\
\text { shoal }\end{array}$ & $\begin{array}{l}\text { The thickness of oncoid-bearing oolitic limestone beds is about } 5.2 \mathrm{~m} \text {. The oncoids vary in } \\
\text { type and size and are widely horizontally distributed. It is overlain by calcareous mudstone } \\
\text { from the lower part of the Gushan Formation, and underlain by massive micritic limestone } \\
\text { interbedded with thin oolitic limestone. }\end{array}$ \\
\hline $\begin{array}{l}\text { Jinzhou Bay } \\
\text { section }\end{array}$ & $\begin{array}{l}\text { Top Zhangxia } \\
\text { Formation }\end{array}$ & $0.7-1.9$ & $\begin{array}{l}\text { Ooid } \\
\text { shoal }\end{array}$ & $\begin{array}{l}\text { The thickness of oncoid-bearing oolitic limestone beds is about } 4.9 \mathrm{~m} \text {. The oncoids vary in } \\
\text { type and size and are widely horizontally distributed. It is overlain by calcareous mudstone } \\
\text { from the lower part of the Gushan Formation, and underlain by massive micritic limestone } \\
\text { interbedded with thin oolitic limestone. }\end{array}$ \\
\hline
\end{tabular}

\subsubsection{Type 2, concentric rough-laminar oncoids}

Concentric rough-laminar oncoids have characteristics similar to those of type 1 oncoids containing concentric laminae (Han et al. 2015). However, the present study classifies them as two independent categories for the following reasons: (1) individual type 2 oncoids are noticeably smaller, and their concentric laminae are very sparse (Fig. 4c); (2) the concentric laminae of type 2 oncoids display light-dark differentiation, with their single lamina being much thicker than that in type 1 oncoids (Fig. 4d); (3) the nucleus volume of type 2 oncoids occupies a larger proportion of the oncoid than does that of type 1 oncoids (Fig. 4c); and (4) Girvanella is absent in the light laminae but present and intertwined in the dark laminae in type 2 oncoids (Fig. 4d). Among the six measured sections, type 2 oncoids are most abundant in the Diaoquan $(14 \%, 28$ of 200$)$ and Xiaweidian (33\%, 66 in 200) sections, and accounts for $5 \%$ (10 of 200) in the Wuhai section. However, the proportions drop to $1 \%$ (2 in 200) in the Sandaogou, Fuzhou Bay and Jinzhou Bay sections.

\subsubsection{Type 3, lateral-growth oncoids}

Lateral-growth oncoids show thick alternating light and dark laminae, smooth edges, a high degree of regularity in individuals, and nuclei usually composed of trilobite debris, making these oncoids analogous to type 1 oncoids microscopically.

The differences are that the majority of lateral-growth oncoids are larger than type 1 oncoids, with the nucleus not located in the center (Fig. 5a). The laminae on one side of the nucleus are thick and well-developed, whereas they are thin and poorly-developed on the other side (Fig. 5b). Some dispersed sparry calcite microcrystals are observed inside the laminae, mostly on the well-developed side (Fig. 5c). Girvanella filaments are observed inside the dark micrite with an intertwined arrangement (Fig. 5b) or aligned parallel to the laminae with an ideal orientation (Fig. 5c). Type 3 oncoids are observed in the Jinzhou Bay (23\%, 46 in 200), Fuzhou Bay (19\%, 38 in 200) and Sandaogou (19\%, 38 in 200) sections respectively.

\subsubsection{Type 4, multicore oncoids}

Each multicore oncoid typically contains more than two nuclei. They are irregular in shape, mainly long and narrow but occasionally round to subround, and can reach large sizes. The nucleus is often made up of trilobite debris or ooids. The inner laminae near the nucleus are usually concentric (Fig. 6a, b). The relatively outer laminae are composed of light microspar and dark micrite. Typical Girvanella 

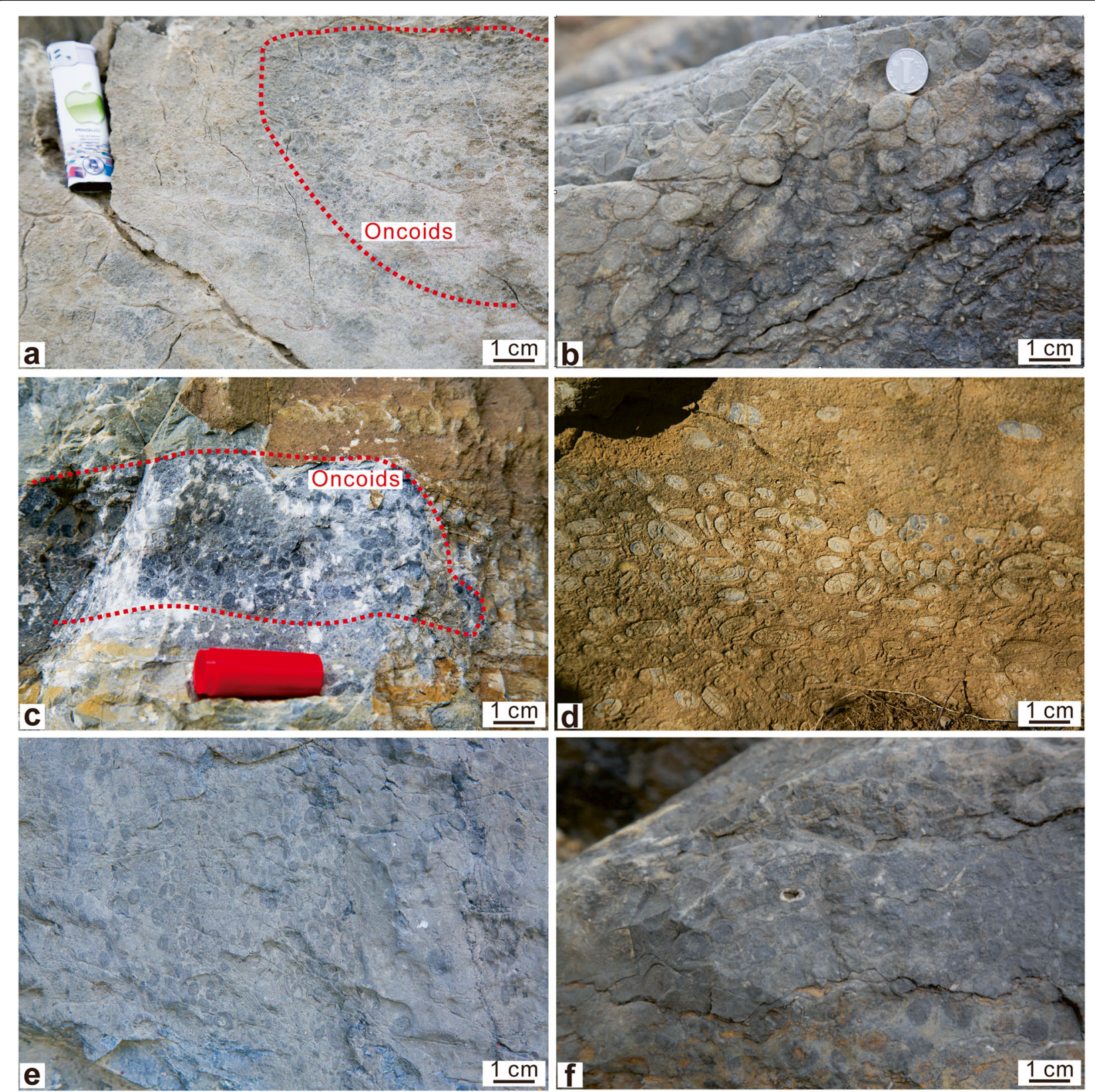

Fig. 3 Macroscopic characteristics of oncoids in the Cambrian Miaolingian Series, North China Platform. a Oncoids from the Xuzhuang Formation, Wuhai section; b Oncoids from the Zhangxia Formation, Diaoquan section; c Oncoids from the Xuzhuang Formation, Xiaweidian section; $\mathbf{d}$ Oncoids from the Zhangxia Formation, Sandaogou section; e Oncoids from the Zhangxia Formation, Fuzhou Bay section; f Oncoids from the Zhangxia Formation, Jinzhou Bay section

filaments are observed inside the dark micritic bands (Fig. 6c, d).

Notably, multicore oncoids are recognized and exhibit similar morphological characteristics in the Diaoquan and Sandaogou sections. However, in the Sandaogou section, they contain light and dark laminae and are analogous to type 1 oncoids (Figs. 6a, 4a), while in the Diaoquan section, the light and dark laminae are poorly developed in the multicore oncoids and are comparable to those of type 2 oncoids (Figs. 6b, 4c).

\subsubsection{Type 5, flaggy oncoids}

Flaggy oncoids differ greatly from other oncoid varieties in shape (Fig. 7a). Their composition is fairly simple and predominantly composed of a nucleus and surrounding 


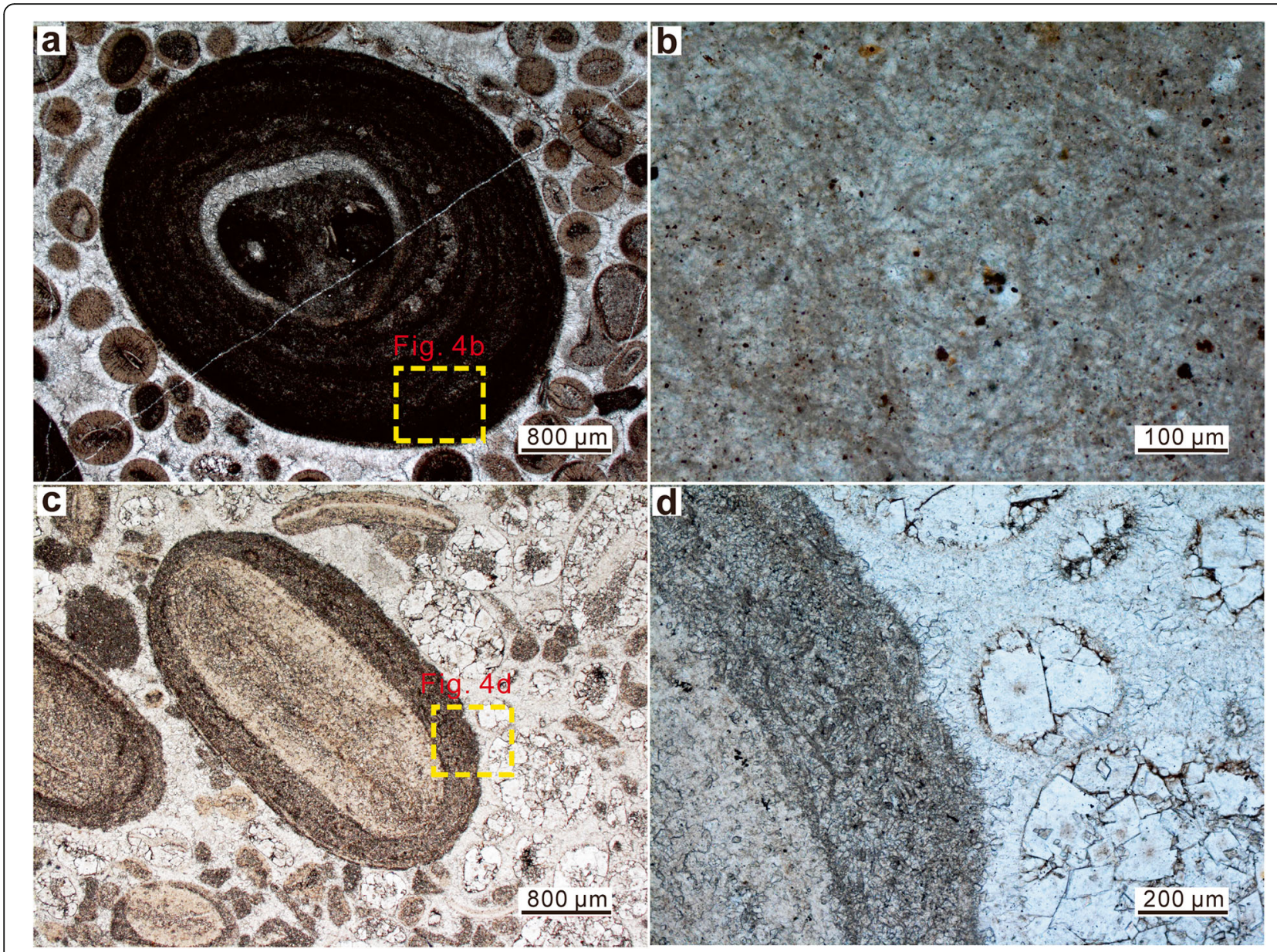

Fig. 4 Microscopic characteristics of types 1 and 2 oncoids. a A type 1 oncoid from the Sandaogou section, characterized by concentric finelaminar structure and clear nucleus (made up with trilobite debris and dark micrite); $\mathbf{b}$ Local magnification of a, showing the interlaced and intertwined calcified filamentous fossils of Girvanella; c A type 2 oncoid from the Diaoquan section, characterized by a concentric rough-laminar structure with lower frequency alternation than that in type 1; d Local magnification of $\mathbf{c}$, showing the micrite conglomeration and rough edges of the oncoid. Girvanella fossils can be observed inside the dark micrite laminae with a disordered winding occurrence

dark micrite layer. The nucleus is made up of slender trilobite debris (Fig. 7a). Only a small number of flaggy oncoids show laminar structures. Most flaggy oncoids are irregular in shape and are much smaller in size than other oncoids. Girvanella filaments are observed inside the dark micritic cortex (Fig. 7b).

Flaggy oncoids are only observed in the Wuhai, Diaoquan and Xiaweidian sections. Importantly, the numbers of flaggy oncoids in these sections differ greatly. The proportion in the Xiaweidian section is only $5.5 \%$ (11 in 200 ) but reaches $26 \%$ (52 in 200) in the Diaoquan section and $42 \%$ (84 in 200) in the Wuhai section.

\subsubsection{Type 6, thin-cortex oncoids}

This type of oncoid is typically determined as thincortex oncoids (Han et al. 2015). They are irregularly shaped and sized (Fig. 7c), with a long axis of 4-6 $\mathrm{mm}$ long, while the short axis is around $800 \mu \mathrm{m}$ long. The nuclei are made up of ooids, trilobite debris and dark micrite grains and are surrounded by a uniform thin dark micritic cortex. Further observations via high-power microscopy reveal the presence of Girvanella (Fig. 7c) inside the dark micrite in these oncoids.

Thin-cortex oncoids are widely distributed in the Wuhai, Diaoquan, Xiaweidian and Jinzhou Bay sections, with different proportions and sizes. The Jinzhou Bay and Xiaweidian sections have minute proportions (3\%, 6 in 200 , and $5 \%, 10$ in 200, respectively) of the total number of oncoids, with measured sizes of approximately $800 \mu \mathrm{m}$ long. However, the proportion reaches $45 \%$ (90 in 200) in the Diaoquan section and 53\% (106 in 200) in the Wuhai section, with sizes of 4-6 $\mathrm{mm}$ long in both sections. 


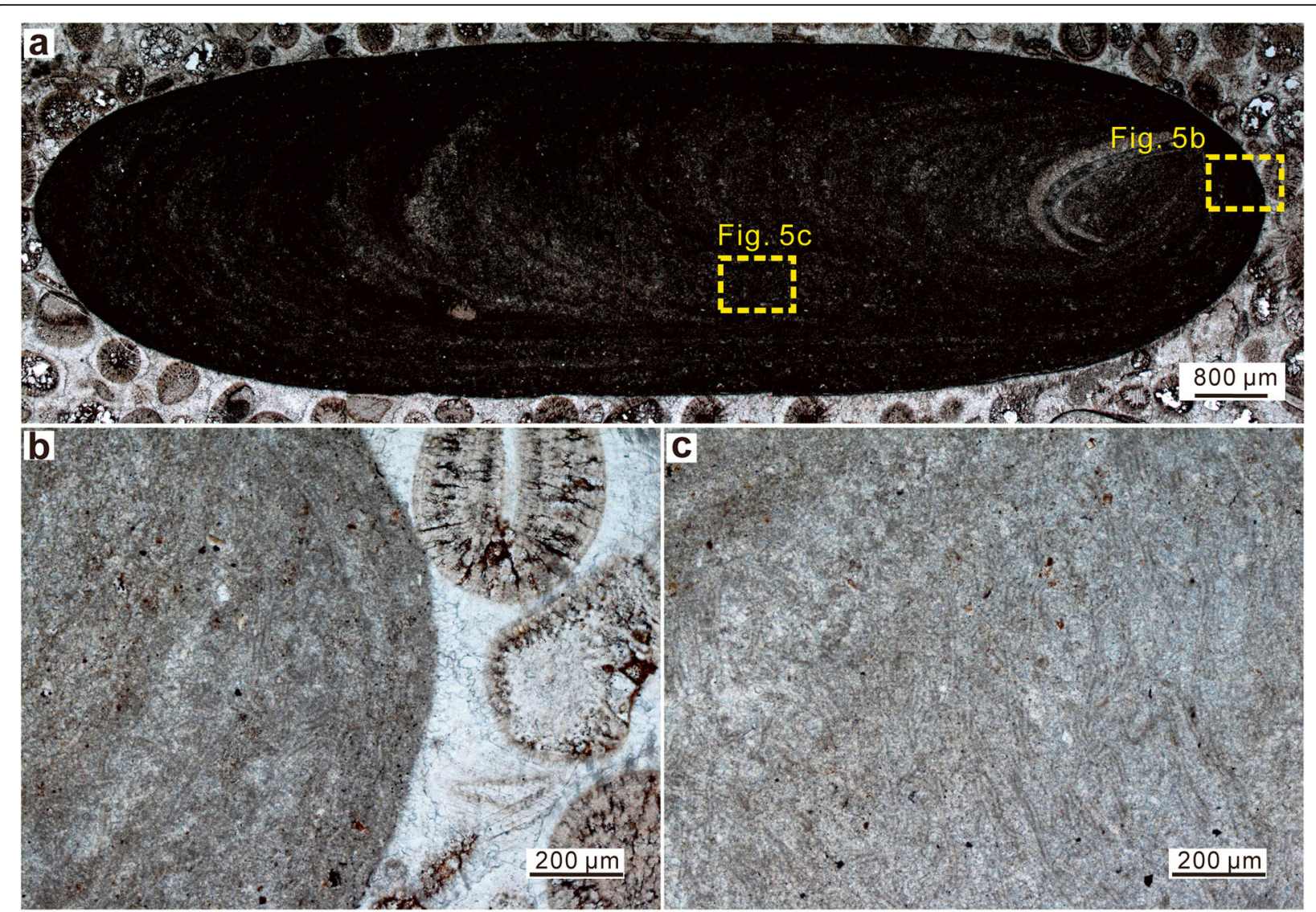

Fig. 5 a A type 3 oncoid, characterized by concentric laminae, an off-center nucleus and lateral growth; $\mathbf{b}$ Local magnification of $\mathbf{a}$, showing the disordered Girvanella fossils with intertwined arrangement; c Local magnification of $\mathbf{a}$, showing the directional arrangement of Girvanella fossils

\subsection{Ultramicroscopic characteristics of oncoids and the mineral composition of lamina}

According to SEM observations, the dark and light laminae of oncoids exhibit different ultrastructures (Fig. 8a, b). The light laminae are composed of $\mathrm{CaCO}_{3}$ microspars (Fig. 8a-c, g), showing welldeveloped cleavage and relatively smooth surfaces. The dark laminae are composed of micrite, whose main component is also $\mathrm{CaCO}_{3}$, showing a distinct morphological structure (Fig. 8a, d, f). The micrite is similar to microbially-derived carbonate mud, which is consistent with the findings of previous studies (Perry 1999; Flügel and Munnecke 2010; Guido et al. 2012; Edgcomb et al. 2013; Kaźmierczak et al. 2015; Gischler et al. 2017; Yu et al. 2019). Moreover, two kinds of pyrite particles are observed in the micrite (Fig. 8e): ordinary massive pyrite and framboidal pyrite. The framboidal pyrite is associated with sulfatereducing bacteria and stimulates the microbial metabolism of carbonate precipitation, which therefore indicates a microbial origin of the studied oncoids (Baumgartner et al. 2006; Xiao et al. 2017c, 2018, 2019b).

\subsection{Geochemical analysis}

In this study, the oncolitic limestones are similar in lithology and strata position; however, the microscopic analysis reveals that oncoids from different sections differ obviously in terms of variety and abundance. To examine whether these differences are linked to the Cambrian palaeogeographic settings of the North China Platform, $\mathrm{XRD}$ and carbon and oxygen isotopic analyses were conducted on the samples of oncolitic limestone collected from the six sections.

\subsubsection{XRD}

Five samples of oncolitic limestone were taken from each section of the Cambrian Miaolingian Series, specifically, from the Xuzhuang and Zhangxia formations, and XRD analysis was performed to determine the basic mineral components (Table 2). The results show that the main mineral component of the oncolitic limestone in the six sections is calcite; however, there are several differences in other mineral components, as follows. (1) In the Jinzhou Bay, Fuzhou Bay, Sandaogou and Xiaweidian sections, the content of quartz in the oncolitic limestone samples is $1 \%-2 \%$, while in 


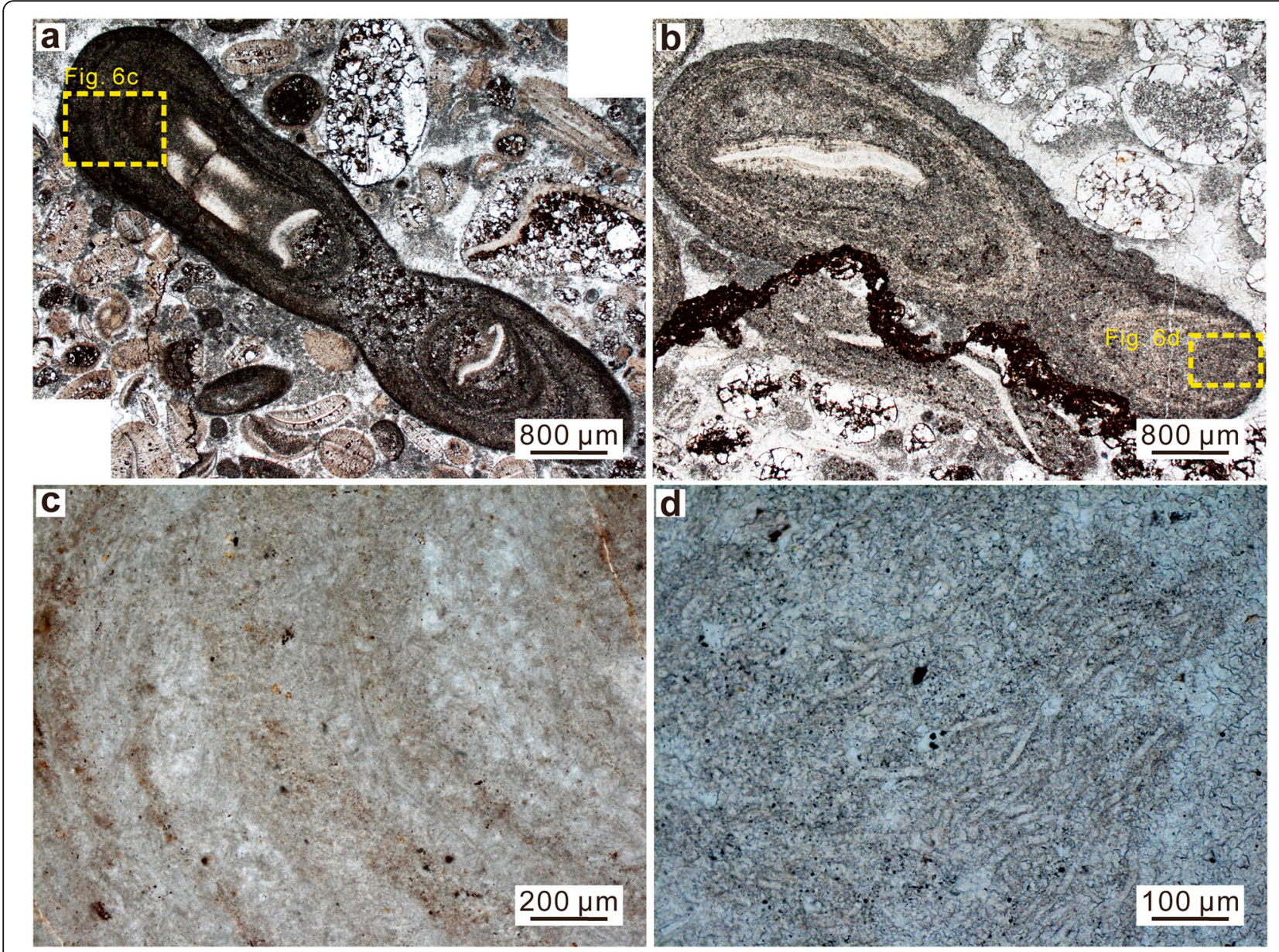

Fig. 6 Microscopic characteristics of type 4 oncoids. a A type 4 oncoid from the Sandaogou section, characterized by a concentric laminar structure and two nuclei (made up of trilobite debris and dark micrite); b A type 4 oncoid from the Diaoquan section, characterized by a concentric rough-laminar structure, unsmooth edges and two nuclei; c Local magnification of a, showing typical Girvanella fossils inside the dark micritic laminae with an intertwined arrangement; $\mathbf{d}$ Local magnification of $\mathbf{b}$, showing typical Girvanella fossils inside the dark micritic laminae

the Wuhai and Diaoquan sections, this value is markedly higher, reaching 9\%. (2) Feldspar is not observed in the samples from the Jinzhou Bay and Fuzhou Bay sections, and its content in the Sandaogou and Xiaweidian sections is extremely low. Conversely, it has relatively higher content in the Wuhai and Diaoquan sections, reaching 4\%. (3) Although dolomite occurs in all six sections, its content is much higher in the Wuhai and Diaoquan sections than in the other sections. (4) Additionally, the contents of pyrite and clay minerals are low and exhibit no obvious regularity.

\subsubsection{Carbon and oxygen isotopes}

Carbon and oxygen isotopic compositions of marine limestone can reflect the sedimentary environment ( $\mathrm{Li}$ et al. 2013, 2017). Therefore, carbon and oxygen isotopic analysis was applied to 30 oncolitic limestone samples to further interpret the depositional environments of oncoids. The results show that the mean $\delta^{13} \mathrm{C}$ values in the Xuzhuang and Zhangxia formations decrease from west to east (Table 3). The mean $\delta^{13} \mathrm{C}$ value of the Xuzhuang Formation in the Wuhai section is $-0.302 \%$ o VPDB, which is higher than those of the Xuzhuang Formation in the Xiaweidian section (-0.788\% VPDB), Fuzhou Bay section (-0.890\% VPDB) and Jinzhou Bay section $(-0.716 \%$ VPDB) (Table 3$)$. In addition, the mean $\delta^{13} \mathrm{C}$ values of the samples from the Zhangxia Formation also exhibit the same pattern, i.e., the mean value of $-0.626 \%$ VPDB in the Diaoquan section (west) is higher than that of $-0.796 \%$ VPDB in the Sandaogou section (east) (Table 3; Fig. 9).

The $\delta^{18} \mathrm{O}$ values in the six sections also exhibit apparent variations. The mean $\delta^{18} \mathrm{O}$ values in the western sections are higher than those in the eastern sections. (1) The value of the Xuzhuang Formation decreases from $-6.664 \%$ VPDB in the Wuhai section to $-8.758 \%$ VPDB in the Xiaweidian section, to $-9.712 \%$ VPDB in the Fuzhou Bay section, and to $-10.404 \%$ VPDB in the 


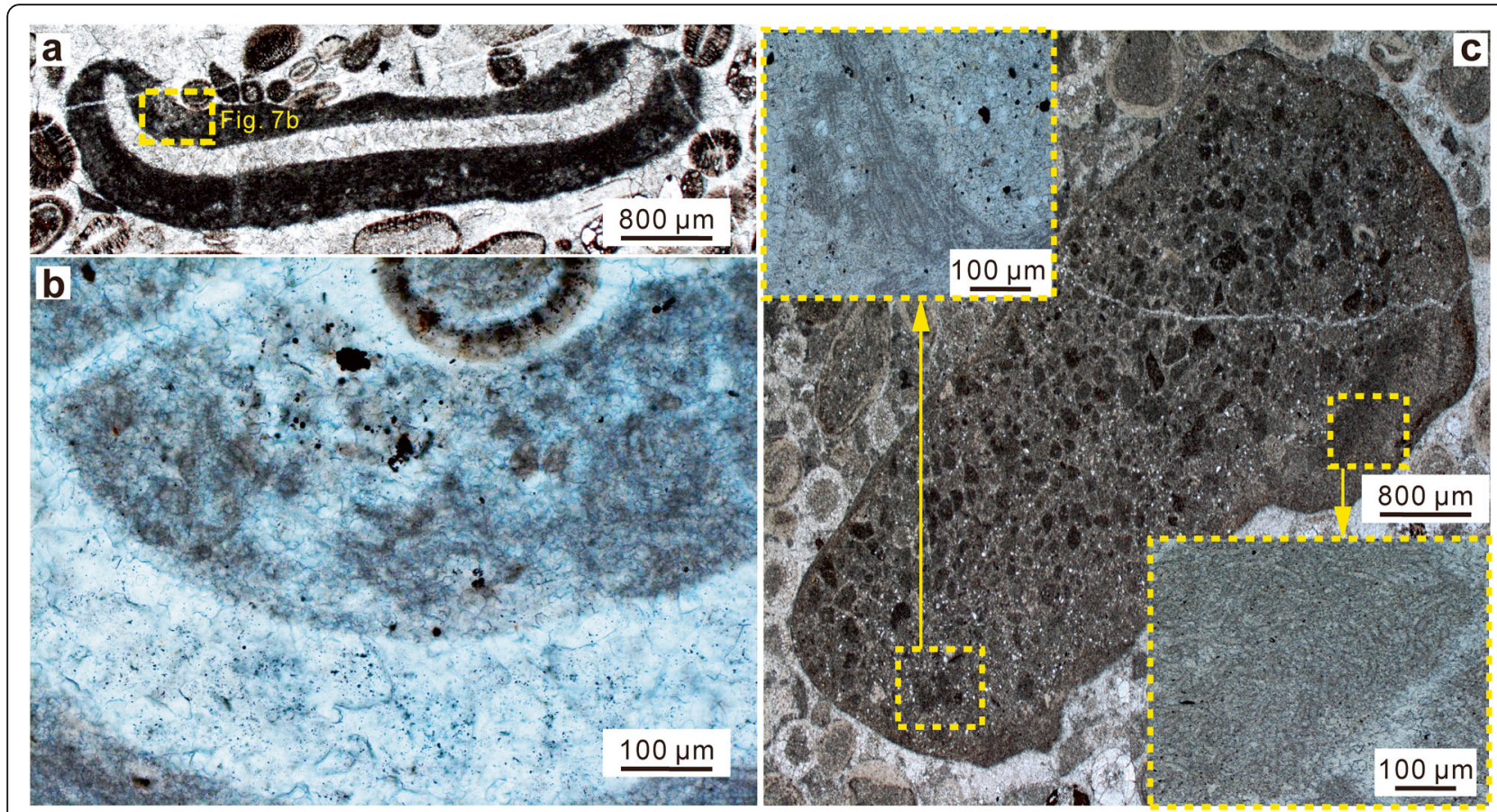

Fig. 7 a A type 5 oncoid, marked by an irregular shape with a clearly external enveloping micritic cortex and the nucleus; b Local magnification of $\mathbf{a}$, showing the typical Girvanella fossils inside the dark micritic cortex. Some spherical cross-sections can be observed; $\mathbf{c}$ A type 6 oncoid, marked by a larger individual size, irregular shape and thin cortex. The local magnifications show the two arrangements of Girvanella fossils, which are parallel and intertwined

Jinzhou Bay section (Table 3; Fig. 9). (2) The value of the Zhangxia Formation in the Diaoquan section is $-6.65 \%$ VPDB, which is higher than that of $-7.854 \%$ o VPDB in the Sandaogou section (Table 3).

\section{Discussion}

The study of ancient oncoids can indicate changes in depositional conditions and the controlling effects of microbial activities on their formation; therefore, the results are important for reconstructing palaeoclimate, palaeoenvironments, sea-level fluctuations and chemical conditions in sedimentary environments (Peryt 1983; Védrine et al. 2007; Védrine 2008; Yang et al. 2011; Zhang et al. 2014a, 2014b; Zhou et al. 2017).

\subsection{Classification and biogenicity of oncoids}

The classification of oncoids has not been comprehensively interpreted and is considered as an important direction of oncoids study (Dahanayake 1977; Peryt 1983). The macro- and microcharacteristics and the mineral compositions of oncoids are influenced by the physical, chemical and biological conditions of the aquatic environment and microbial activity. The current classifications include: (1) morphological classification (Yang et al. 2011); (2) mineral component classification (Flügel and Munnecke 2010); and (3) formational environment classification (Védrine et al. 2007; Védrine 2008). In this study, the classification of oncoids on the basis of morphological characteristics is applied.

The morphological similarities of the oncoids reported in this study compared to those of previous works on oncoids in similar or different environments suggest that the oncoids in the Cambrian Miaolingian Series, North China Platform, are microbial in origin (Table 4) (Krumbein and Cohen, 1977; Zeng et al, 1983; Gerdes et al, 1994; Davaud and Girardclos, 2001; Flügel and Munnecke, 2010; Jones, 2011; Han et al, 2015; Wang and Xiao, 2018). Typical filamentous cyanobacterial fossils, including Girvanella (Riding 2011; Xiao et al. 2018), are abundant among the oncoids in this study (Figs. 4-7), which is clearly related to microorganisms and indicates that the origin of these oncoids is associated with the calcification of cyanobacteria-dominated microbial communities and the biodegradation of heterotrophic bacteria. The framboidal pyrite particles were produced by the sulfate reduction reaction dominated by sulfate-reducing bacteria (Fig. 8e) (Xiao et al. 2017c, 2019b).

As concluded in the above discussion, the oncoids in this study are predominantly composed of calcite. The alternation of light and dark laminae is associated with different microstructures of the calcium carbonate minerals (Fig. 8a, b). The light laminae are composed of calcite microspar, whereas the dark laminae are mainly composed of amorphous calcium carbonate (ACC), 


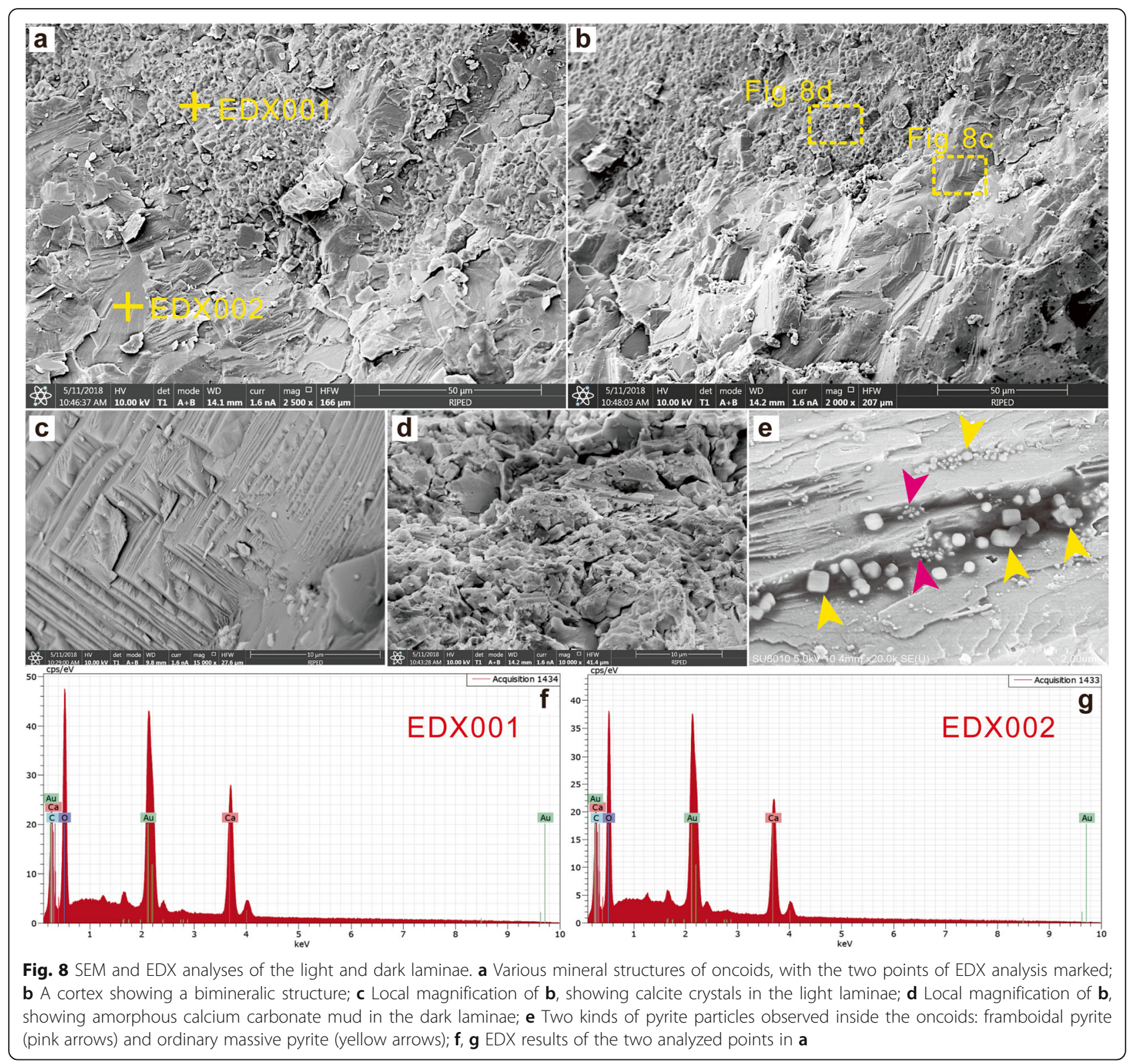

which is inferred to be the product of Girvanella calcification (Pratt 2001) and can be comparable to previously documented examples of ACC (Jones and Peng 2012; Diaz et al., 2017). Similarly, the discovery of Girvanella inside oncoids and the ultrastructure of the dark micrite laminae, including the presence of framboidal pyrite, are likely related to cyanobacteria-dominated calcification and the involvement of heterotrophic bacteria in the promotion of calcium carbonate precipitation (Dupraz et al. 2009).

\subsection{Response to palaeogeography and palaeoenvironment}

The formation process of an oncoid can be inferred from its structure and form, including the nucleus development, concentric laminae, and cortex morphological characteristics. It is controlled by palaeogeographic and palaeoenvironmental factors, such as the water and atmospheric chemical conditions, as well as sea-level changes (Védrine et al. 2007; Védrine 2008). Therefore, the study of the morphology and origin of oncoids may provide remarkable insights for reconstructing palaeogeography and palaeoenvironments (Peryt 1983; Yang et al. 2011; Zhang et al. 2013, 2015; Zhou et al. 2017).

The oncoids from the six sections developed during approximately the same period. This study based on sedimentology and stratigraphy, in combination with previous reports on the Cambrian palaeogeography of the North China Platform (Feng 2004; Ma et al. 2017), 
Table 2 XRD analysis results showing the mineral compositions and contents of the oncolitic limestone from the Cambrian Miaolingian Series, North China Platform

\begin{tabular}{|c|c|c|c|c|c|c|c|}
\hline \multirow[t]{2}{*}{ Section name } & \multirow{2}{*}{$\begin{array}{l}\text { Sample } \\
\text { number }\end{array}$} & \multicolumn{6}{|c|}{ Mineral composition and content (\%) } \\
\hline & & $\overline{\text { Quartz }}$ & Potassium feldspar & Calcite & Dolomite & Pyrite & Clay minerals \\
\hline \multirow[t]{5}{*}{ Wuhai section } & WHXZ-1 & 4 & 2 & 86 & 6 & 1 & 1 \\
\hline & WHXZ-2 & 7 & 3 & 79 & 9 & / & 2 \\
\hline & WHXZ-3 & 2 & 2 & 89 & 6 & 1 & / \\
\hline & WHXZ-4 & 5 & 4 & 83 & 7 & / & 1 \\
\hline & WHXZ-5 & 8 & 2 & 80 & 10 & / & / \\
\hline \multirow[t]{5}{*}{ Diaoquan section } & DQZX-1 & 2 & 1 & 82 & 15 & / & / \\
\hline & DQZX-2 & 3 & 2 & 83 & 11 & 1 & / \\
\hline & DQZX-3 & 9 & 2 & 79 & 10 & / & / \\
\hline & DQZX-4 & 8 & 4 & 75 & 13 & / & / \\
\hline & DQZX-5 & 8 & 4 & 75 & 13 & / & / \\
\hline \multirow[t]{5}{*}{ Xiaweidian section } & XWDXZ-1 & 2 & / & 95 & 3 & / & / \\
\hline & XWDXZ-2 & 1 & / & 94 & 4 & 1 & / \\
\hline & XWDXZ-3 & 1 & 1 & 93 & 5 & / & / \\
\hline & XWDXZ-4 & 1 & / & 94 & 4 & 1 & / \\
\hline & XWDXZ-5 & 1 & 1 & 95 & 2 & 1 & / \\
\hline \multirow[t]{5}{*}{ Sandaogou section } & SDGZX-1 & 2 & 1 & 95 & 1 & / & 1 \\
\hline & SDGZX-2 & 2 & / & 97 & / & 1 & / \\
\hline & SDGZX-3 & 2 & / & 95 & 2 & / & 1 \\
\hline & SDGZX-4 & 2 & 2 & 94 & 1 & 1 & / \\
\hline & SDGZX-5 & 1 & / & 95 & 1 & 1 & 2 \\
\hline \multirow[t]{5}{*}{ Fuzhou Bay section } & $F Z X Z-1$ & 2 & / & 96 & 2 & / & / \\
\hline & $F Z X Z-2$ & 1 & / & 98 & 1 & / & / \\
\hline & $F Z X Z-3$ & 2 & / & 97 & 1 & / & / \\
\hline & $F Z X Z-4$ & / & / & 97 & 2 & / & 1 \\
\hline & FZXZ-5 & 1 & / & 98 & 1 & / & / \\
\hline \multirow[t]{5}{*}{ Jinzhou Bay section } & $J Z X Z-1$ & 1 & / & 97 & 1 & 1 & / \\
\hline & $J Z X Z-2$ & 1 & / & 97 & 2 & / & / \\
\hline & $J Z X Z-3$ & 2 & / & 98 & / & / & / \\
\hline & $J Z X Z-4$ & / & / & 99 & 1 & / & / \\
\hline & $J Z X Z-5$ & 1 & / & 98 & 1 & / & / \\
\hline
\end{tabular}

clarifies that the thicknesses of the oncolitic limestone in the two sections of nearshore environment $(0.3 \mathrm{~m}$ thick in the Wuhai section and $2.2 \mathrm{~m}$ thick in the Diaoquan section) are obviously thinner than those in the other four sections of offshore setting (Table 1). Additionally, macroscopic observations in the field show that the Xuzhuang Formation in the Diaoquan section and Wuhai section has more crossbeds and scouring surfaces. These characteristics can be explained by the fact that sea-level change on a steeper slope resulted in more rapid environmental changes over time, which caused the smaller thicknesses of the oncolitic limestone in the Wuhai and Diaoquan sections.

In addition, there are obvious differences in the types and proportions of each type of oncoids in each section (Fig. 10). In total, 200 oncoid individuals were randomly selected from each section for microscopic observation. Based on their morphology, six types of oncoids were classified, and their proportions in each section were determined. The results demonstrate that the types and 
Table 3 Carbon and oxygen isotopes of the oncolitic limestone samples from the Cambrian Miaolingian Series, North China Platform

\begin{tabular}{|c|c|c|c|c|c|}
\hline Section name & Sample number & $\delta^{13} \mathrm{C}(\% \circ \mathrm{VPDB})$ & Mean $\delta^{13} \mathrm{C}(\% \circ$ VPDB) & $\delta^{18} \mathrm{O}(\% \circ \mathrm{VPDB})$ & Mean $\delta^{18} \mathrm{O}(\%$ VPDB $)$ \\
\hline \multirow[t]{5}{*}{ Wuhai section } & WHXZ-1 & -0.38 & \multirow{5}{*}{-0.302} & -6.38 & \multirow{5}{*}{-6.664} \\
\hline & WHXZ-2 & -0.12 & & -6.12 & \\
\hline & WHXZ-3 & -0.09 & & -6.22 & \\
\hline & WHXZ-4 & -0.27 & & -7.18 & \\
\hline & WHXZ-5 & -0.65 & & -7.42 & \\
\hline \multirow[t]{5}{*}{ Diaoquan section } & DQZX-1 & -1.01 & \multirow{5}{*}{-0.626} & -6.21 & \multirow{5}{*}{-6.650} \\
\hline & DQZX-2 & -0.77 & & -7.02 & \\
\hline & DQZX-3 & -0.83 & & -6.32 & \\
\hline & DQZX-4 & -0.21 & & -7.45 & \\
\hline & DQZX-5 & -0.31 & & -6.25 & \\
\hline \multirow[t]{5}{*}{ Xiaweidian section } & XWDXZ-1 & -0.78 & \multirow{5}{*}{-0.788} & -9.41 & \multirow{5}{*}{-8.758} \\
\hline & XWDXZ-2 & -0.83 & & -9.02 & \\
\hline & XWDXZ-3 & -0.69 & & -8.32 & \\
\hline & XWDXZ-4 & -0.72 & & -8.59 & \\
\hline & XWDXZ-5 & -0.92 & & -8.45 & \\
\hline \multirow[t]{5}{*}{ Sandaogou section } & SDGZX-1 & -0.94 & \multirow{5}{*}{-0.796} & -8.50 & \multirow{5}{*}{-7.854} \\
\hline & SDGZX-2 & -0.57 & & -7.69 & \\
\hline & SDGZX-3 & -0.95 & & -7.99 & \\
\hline & SDGZX-4 & -0.73 & & -8.11 & \\
\hline & SDGZX-5 & -0.79 & & -6.98 & \\
\hline \multirow[t]{5}{*}{ Fuzhou Bay section } & $F Z X Z-1$ & -0.73 & \multirow{5}{*}{-0.890} & -10.01 & \multirow{5}{*}{-9.712} \\
\hline & FZXZ-2 & -0.56 & & -10.48 & \\
\hline & FZXZ-3 & -1.03 & & -9.94 & \\
\hline & $F Z X Z-4$ & -1.16 & & -8.59 & \\
\hline & FZXZ-5 & -0.97 & & -9.54 & \\
\hline \multirow[t]{5}{*}{ Jinzhou Bay section } & $J Z X Z-1$ & -0.77 & \multirow{5}{*}{-0.716} & -9.65 & \multirow{5}{*}{-10.404} \\
\hline & $J Z X Z-2$ & -0.95 & & -9.92 & \\
\hline & $J Z X Z-3$ & -0.46 & & -11.52 & \\
\hline & $J Z X Z-4$ & -0.88 & & -10.22 & \\
\hline & $J Z X Z-5$ & -0.52 & & -10.71 & \\
\hline
\end{tabular}

proportions of different types of oncoids have the following patterns. (1) Oncoids with well-developed laminae (type 1, concentric fine-laminar oncoids, and type 3, lateral-growth oncoids) mostly develop in sections of offshore environment (Fig. 10a). (2) Oncoids with poorlydeveloped laminae (type 2, concentric rough-laminar oncoids) and irregular oncoids (type 5, flaggy oncoids, and type 6 , thin-cortex oncoids) predominantly occur in the two sections of nearshore setting (Wuhai and Diaoquan sections) (Fig. 10a). The proportions of the most abundant oncoid varieties (types 5 and 6) are 95\% and
$71 \%$ in the Wuhai and Diaoquan sections, respectively. In contrast, in the Jinzhou Bay section, type 6 oncoids account for only $3 \%$ (Fig. 10a). (3) Type 4 oncoids only occur in the Zhangxia Formation in the study area and comprise only a small proportion (14\% in the Diaoquan section and $8 \%$ in the Sandaogou section).

These clear patterns can be summarized as follows. Oncoids with fine laminae, clear cores and regular shapes exist in almost all offshore sections, and in contrast, oncoids with poorly-developed laminae and irregular shapes occur in nearshore sections (Fig. 10a). These 


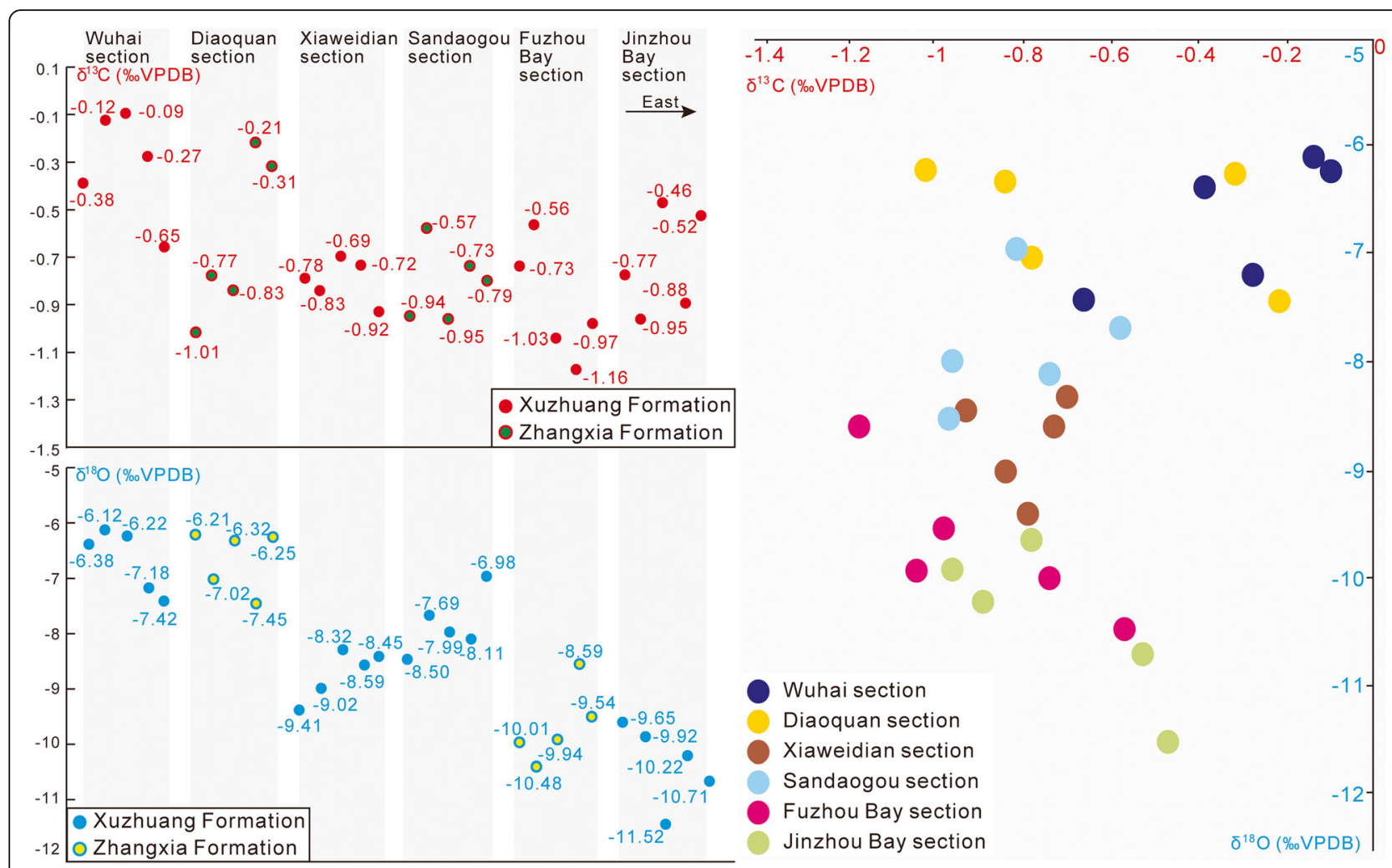

Fig. 9 C-O isotopic data for the oncolitic limestone from the Cambrian Miaolingian Series, North China Platform. The progressive decreasing trend of carbon and oxygen isotopic data from west to east can be obviously observed

patterns are also perceptibly associated with the main mineral compositions (Table 2; Fig. 10b, c) and the carbon and oxygen isotopic compositions (Table 3; Figs. 9, 10d, e) of the oncoids in different sections. The XRD results confirm that the proportions of quartz and feldspar in the two nearshore sections (i.e., the Wuhai and Diaoquan sections) are significantly higher than those of the offshore sections (Table 2; Fig. 10b, c), which suggests that the carbonate sediments contain more terrigenous clasts. The presence of dolomite indicates the occurrence of dolomitization (burial, evaporation, etc.) caused by the shallowing depositional environment during the process of relative sea-level fall (Fig. 2) (Kendall and Schlager 1981; Hardie 1987; Xiao et al. 2017c). The occurrence of detrital quartz and feldspar signifies the input of terrigenous clasts during the deposition of the limestone and indicates that the depositional environment of the oncolitic limestone was characterized by shallow water and offshore conditions.

The results of the isotopic study show that the carbon and oxygen isotope values exhibit a decreasing trend from west to east (Table 3; Fig. 10d, e). The $\delta^{18} \mathrm{O}$ and $\delta^{13} \mathrm{C}$ trends can be further explained as signifying the depositional environment changing from west to east during the same period in the North China Platform. This observation also confirms the macroscopic sedimentology and stratigraphic inference that the depositional environment of Wuhai and Diaoquan sections differed from that of Xiaweidian, Sandaogou, Fuzhou Bay and Jinzhou Bay sections (Table 1; Figs. 1, 2). The results are consistent with the palaeogeographic conditions of the sections and signify that the nearshore sections are dominated by higher carbon and oxygen isotopic values and that the offshore sections are dominated by lower isotopic values. This isotopic trend reflects geochemical changes related to differences in the depositional environments of the six sections, which may have been controlled by terrigenous inputs. Furthermore, the variations in the palaeoenvironmental conditions had a noticeable impact on the occurrence of oncoids in different sections. For example, types 2, 5 and 6 oncoids are the main oncoid varieties produced in the nearshore sections, whereas types 1 and 3 oncoids are the main types produced in the offshore sections (Fig. 10a-c).

These features are evident in the morphological characteristics of two groups of oncoids from the Zhangxia Formation in the Diaoquan and Sandaogou sections. Multicore oncoids (type 4) only occur in these two sections (Fig. 10a). In the Sandaogou section, the laminae of multicore oncoids are distinct, and the oncoid morphology is irregular due to the multiple nuclei and the 
Table 4 Morphological classification of oncoids from the Cambrian Miaolingian Series in the study area

\begin{tabular}{|c|c|c|c|c|c|}
\hline Types & $\begin{array}{l}\text { Nomenclature } \\
\text { in this study }\end{array}$ & $\begin{array}{l}\text { Diameter of } \\
\text { oncoids } \\
(\mathrm{cm})\end{array}$ & $\begin{array}{l}\text { Microbial } \\
\text { fossil and } \\
\text { pyrite }\end{array}$ & Occurring sections & Formation mechanism \\
\hline Type 1 & $\begin{array}{l}\text { Concentric } \\
\text { fine-laminar } \\
\text { oncoids }\end{array}$ & $0.6-1.4$ & $\begin{array}{l}\text { Girvanella, } \\
\text { pyrite }\end{array}$ & $\begin{array}{l}\text { Xiaweidian, } \\
\text { Sandaogou, } \\
\text { Fuzhou Bay, and } \\
\text { Jinzhou Bay } \\
\text { sections }\end{array}$ & $\begin{array}{l}\text { Spherical stromatolites (Krumbein and Cohen 1977); } \\
\text { Envelope growth of algae adhering to granules (Zeng et al. } \\
\text { 1983); } \\
\text { Biodegradation of heterotrophic bacteria and algae residues } \\
\text { in microbial mats (Mesozoic reports related to diatoms) } \\
\text { (Gerdes et al. 1994); } \\
\text { Cyanobacteria calcification and EPS degradation cooperate } \\
\text { with strong hydrodynamic forces (Wang and Xiao 2018) }\end{array}$ \\
\hline Type 2 & $\begin{array}{l}\text { Concentric } \\
\text { rough-laminar } \\
\text { oncoids }\end{array}$ & $0.2-0.8$ & Girvanella & $\begin{array}{l}\text { Wuhai, } \\
\text { Diaoquan, and } \\
\text { Xiaweidian } \\
\text { sections }\end{array}$ & $\begin{array}{l}\text { Cyanobacteria calcification and EPS degradation cooperate } \\
\text { with weak hydrodynamic forces (Wang and Xiao 2018) }\end{array}$ \\
\hline Type 3 & $\begin{array}{l}\text { Lateral-growth } \\
\text { oncoids }\end{array}$ & $0.8-2.2$ & $\begin{array}{l}\text { Girvanella, } \\
\text { pyrite }\end{array}$ & $\begin{array}{l}\text { Sandaogou, } \\
\text { Fuzhou Bay, and } \\
\text { Jinzhou Bay } \\
\text { sections }\end{array}$ & $\begin{array}{l}\text { Cyanobacteria calcification and EPS degradation focusing } \\
\text { on the weight of the nucleus cooperate with weak } \\
\text { hydrodynamic forces (Wang and Xiao 2018) }\end{array}$ \\
\hline Type 4 & $\begin{array}{l}\text { Multicore } \\
\text { oncoids }\end{array}$ & $0.9-2.3$ & $\begin{array}{l}\text { Girvanella, } \\
\text { pyrite }\end{array}$ & $\begin{array}{l}\text { Diaoquan, and } \\
\text { Sandaogou } \\
\text { sections }\end{array}$ & $\begin{array}{l}\text { Bonding of amicrobial communities on the surface of } \\
\text { oncoids (Flügel and Munnecke 2010); } \\
\text { Encapsulation of biofilm (Wang and Xiao 2018) }\end{array}$ \\
\hline & Flaggy oncoids & $0.2-0.8$ & Girvanella & $\begin{array}{l}\text { Wuhai, } \\
\text { Diaoquan, and } \\
\text { Xiaweidian } \\
\text { sections }\end{array}$ & $\begin{array}{l}\text { Close association with organic films formed by mucus and } \\
\text { produced by filamentous cyanobacteria and diatoms } \\
\text { (Davaud and Girardclos 2001); } \\
\text { Production of filamentous cyanobacteria calcification inside } \\
\text { the microbial mat (Wang and Xiao 2018). }\end{array}$ \\
\hline Type 6 & $\begin{array}{l}\text { Thin-cortex } \\
\text { oncoids }\end{array}$ & $1.2-2.4$ & $\begin{array}{l}\text { Girvanella, } \\
\text { Bacinella, } \\
\text { pyrite }\end{array}$ & $\begin{array}{l}\text { Wuhai, } \\
\text { Diaoquan, } \\
\text { Xiaweidian, and } \\
\text { Jinzhou Bay } \\
\text { sections }\end{array}$ & $\begin{array}{l}\text { Degradation of EPS and calcification of filamentous } \\
\text { microorganisms (Jones 2011); } \\
\text { Chaotic microbial aggregation bioturbated (Han et al. } \\
\text { 2015); } \\
\text { Biofilm calcification inside the microbial mat bioturbated } \\
\text { (Wang and Xiao 2018) }\end{array}$ \\
\hline
\end{tabular}

inner and outer laminae in the cortex of these oncoids, whereas in the Diaoquan section, the inner laminae are relatively rough, with an extremely irregular cortex (Fig. $6 a, b)$. Additionally, the closer location of these oncoids related to the ancient Yimeng landmass resulted in a greater influence of terrigenous debris, greater salinity and higher overall topography. These factors resulted in a shorter time required for the development of cyanobacteria (Girvanella)-dominated microbial mats and caused the formation of oncoids with less-exquisite laminae and less-regular shapes (Fig. 10a). In contrast, the offshore sections are featured by a more favorable environment with less interference from terrigenous debris and a gentler terrain, which provided a stable environment for cyanobacteria (Girvanella)-dominated microbial mats and promoted oncoids with well-developed laminae and regular shapes.

\section{Conclusions}

1) Six Cambrian sections in the North China Platform contain exquisitely preserved oncoids with different shapes in the Xuzhuang and Zhangxia formations of the Miaolingian Series. Based on the morphologies and internal structures revealed by microscopy, the oncoids can be divided into six types: type 1, concentric finelaminar oncoids; type 2, concentric rough-laminar oncoids; type 3, lateral-growth oncoids; type 4, multicore oncoids; type 5, flaggy oncoids; and type 6, thin-cortex oncoids.

2) The morphological and ultrastructural characteristics and XRD results of the oncoid samples reveal the presence of carbonate minerals, predominantly calcite. SEM observations of the oncoid microstructure indicate that the light laminae are composed of calcite microspar and that the dark laminae are composed of ACC. Girvanella fossils and framboidal pyrite can be found inside oncoids. These observations suggest a biogenic origin of the Cambrian oncoids exposed in the North China Platform. These oncoids are inferred to have formed through the interaction between cyanobacteria and heterotrophic bacteria (sulfate-reducing bacteria) inside microbial mats.

3) The occurrence of detrital quartz and feldspar in the oncolitic limestone in the Cambrian Xuzhuang and Zhangxia formations signifies the input of terrigenous clasts. The presence of small amounts of dolomite suggests a shallowing depositional environment during relative sea-level fall. The carbon and oxygen isotopes 


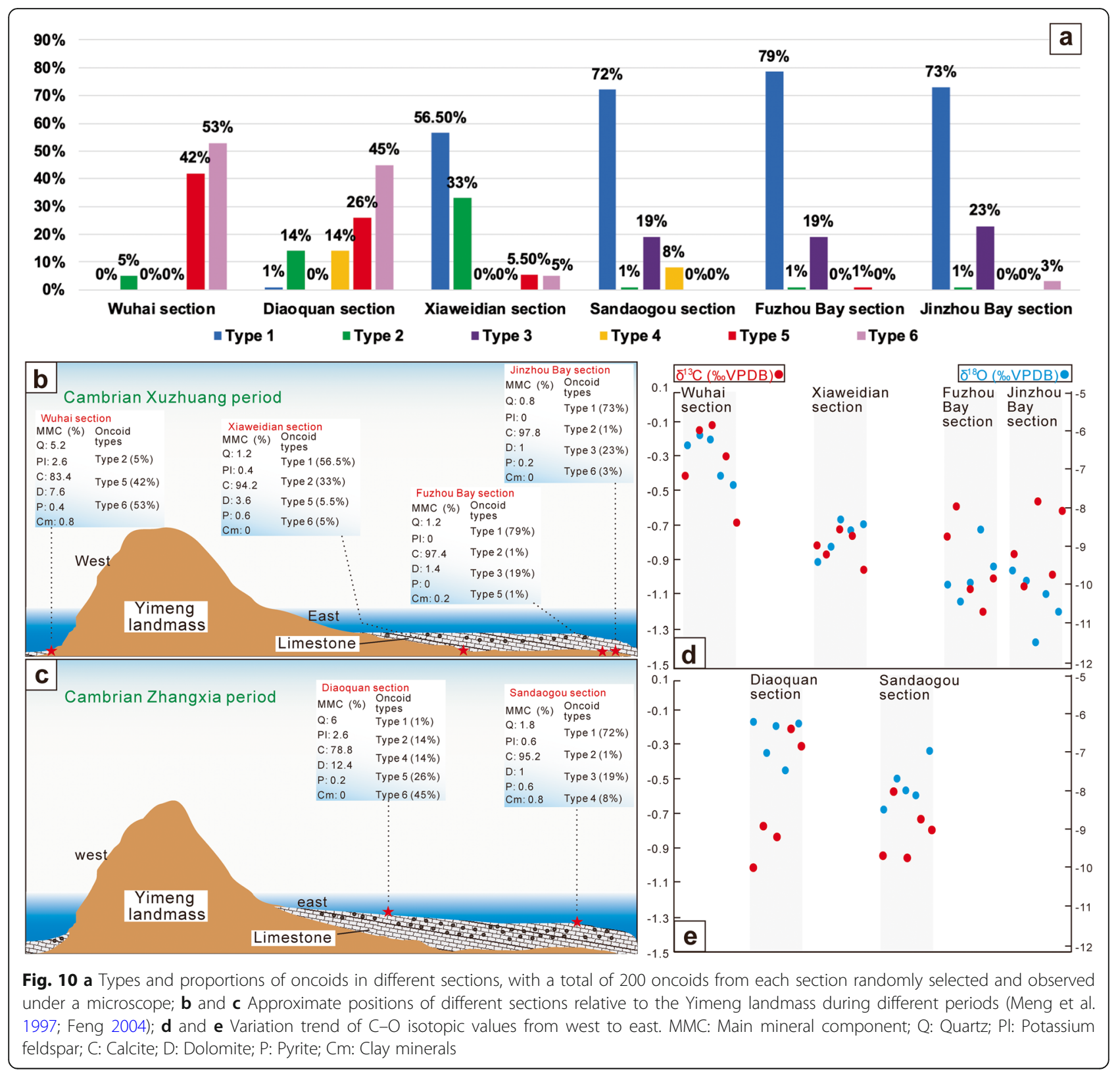

further imply that the formational environments of the oncolitic limestone varied spatially in the study area. The oncoids in nearshore environments were significantly influenced by the terrigenous input, and the steeper terrain resulted in relatively rapid changes in accommodation space during sea-level changes, resulting in rougher oncoid growth (rough and indelicate laminae, uneven cortex, and irregular shape). In contrast, the oncoids that developed in offshore sections were less affected by terrigenous factors, resulting in an environment favorable for the production of exquisite oncoids in cyanobacteria (Girvanella)-dominated microbial mats in a stable carbonate platform that was comparatively flat in the east.

\section{Abbreviations}

ACC: Amorphous calcium carbonate; EDX: Energy dispersive X-ray spectroscopy; MMC: Main Mineral Component; PPL: Plane-polarized light; SEM: Scanning electron microscopy/microscope; VPDB: Vienna pee dee belemnite; XPL: Cross-polarized light; XRD: X-ray diffraction

\section{Acknowledgements}

We gratefully acknowledge Prof. Zeng-Zhao Feng for the critical review of the earlier version of the manuscript. We are also thankful for the help from Dr. Muhammad Riaz and Dr. Khalid Latif in the field work.

\section{Authors' contributions}

EZX proposed the viewpoint, carried out the analysis, and wrote the manuscript. MXM instructed the field work. SJ instructed the manuscript writing. TZ improved the language. All authors read and approved the final manuscript. 


\section{Funding}

National Natural Science Foundation of China (Nos. 41472090 and 40472065).

\section{Availability of data and materials}

The data used to support the findings of this study are available from the corresponding author upon request.

\section{Competing interests}

The authors declare that they have no competing interests.

\section{Author details}

${ }^{1}$ School of Earth Sciences and Resources, China University of Geosciences (Beijing), Beijing 100083, China. ${ }^{2}$ Key Laboratory of Tectonics and Petroleum Resources of Ministry of Education and Faculty of Earth Resources, China University of Geosciences (Wuhan), Wuhan 430074, China. ${ }^{3}$ Institute of Geochemistry, Chinese Academy of Sciences, Guiyang 550081, China. ${ }^{4}$ Institute of Geology, University of the Punjab, Lahore 54590, Pakistan.

\section{Received: 15 May 2019 Accepted: 16 January 2020}

\section{Published online: 28 February 2020}

\section{References}

Baumgartner, L.K., R.P. Reid, C. Dupraz, A.W. Decho, D.H. Buckley, J.R. Spear, K.M. Przekop, and P.T. Visscher. 2006. Sulfate reducing bacteria in microbial mats: Changing paradigms, new discoveries. Sedimentary Geology 185 (3-4): 131-145.

Dahanayake, K. 1977. Classification of oncoids from the upper Jurassic carbonates of the French Jura. Sedimentary Geology 18 (4): 337-353.

Davaud, E., and S. Girardclos. 2001. Recent freshwater ooids and oncoids from western Lake Geneva (Switzerland): Indications of a common organically mediated origin. Journal of Sedimentary Research 71 (3): 423429

Diaz, M.R., G.P. Eberli, P. Blackwelder, B. Phillips, and P.K. Swart. 2017. Microbially mediated organomineralization in the formation of ooids. Geology 45 (9): 771-774.

Dupraz, C., R.P. Reid, O. Braissant, A.W. Decho, R.S. Norman, and P.T. Visscher. 2009. Processes of carbonate precipitation in modern microbial mats. Earth-Science Reviews 96 (3): 141-162.

Edgcomb, V.P., J.M. Bernhard, D. Beaudoin, S. Pruss, P.V. Welander, F. Schubotz, S. Mehay, A.L. Gillespie, and R.E. Summons. 2013. Molecular indicators of microbial diversity in oolitic sands of Highborne cay, Bahamas. Geobiology 11 (3): 234-251.

Feng, Z.Z. 2004. Lithofacies Palaeogeography of the Cambrian and Ordovician in China, 8-9. Beijing: Petroleum Industry Press (in Chinese).

Flügel, E., and A. Munnecke. 2010. Microfacies of carbonate rocks, 128-129. Berlin: Springer-Verlag.

Gerdes, G., K. Dunajtschik-Piewak, H. Riege, A.G. Taher, W.E. Krumbein, and H.E. Reineck. 1994. Structural diversity of biogenic carbonate particles in microbial mats. Sedimentology 41 (6): 1273-1294.

Gischler, E., K. Heindel, D. Birgel, B. Brunner, J. Reitner, and J. Peckmann. 2017. Cryptic biostalactites in a submerged karst cave of the Belize barrier reef revisited: Pendant bioconstructions cemented by microbial micrite. Palaeogeography, Palaeoclimatology, Palaeoecology 468: 34-51.

Gradziński, M., J.A. Tyszka, A. Uchman, and R. Jach. 2004. Large microbialforaminiferal oncoids from condensed lower-middle Jurassic deposits: A case study from the Tatra Mountains, Poland. Palaeogeography, Palaeoclimatology, Palaeoecology 213 (1-2): 133-151.

Guido, A., A. Vescogni, A. Mastandrea, F. Demasi, F. Tosti, A. Naccarato, A. Tagarelli, and F. Russo. 2012. Characterization of the micrites in the Late Miocene vermetid carbonate bioconstructions, Salento peninsula, Italy: Record of a microbial/metazoan association. Sedimentary Geology 263264: $133-143$

Han, Z.Z., X.L. Zhang, N.J. Chi, M. Han, J. Woo, H.S. Lee, and J.T. Chen. 2015. Cambrian oncoids and other microbial-related grains on the North China platform. Carbonates and Evaporites 30 (4): 373-386.

Hardie, L.A. 1987. Dolomitization: A critical view of some current views. Journal of Sedimentary Petrology 57 (1): 166-183.
Jones, B. 1992. Void-filling deposits in karst terrains of isolated oceanic islands: A case study from tertiary carbonates of the Cayman Islands. Sedimentology 39 (5): 857-876.

Jones, B. 2011. Biogenicity of terrestrial oncoids formed in soil pockets, Cayman Brac, British West Indies. Sedimentary Geology 236 (1-2): 95-108.

Jones, B., and X.T. Peng. 2012. Amorphous calcium carbonate associated with biofilms in hot spring deposits. Sedimentary Geology 269-270: 58-68.

Jones, B., and R.W. Renaut. 1997. Formation of silica oncoids around geysers and hot springs at El Tatio, northern Chile. Sedimentology 44 (2): 287-304.

Jones, B., and R.W. Renaut. 2010. Impact of seasonal changes on the formation and accumulation of soft siliceous sediments on the discharge apron of Geysir, Iceland. Journal of Sedimentary Research 80 (1): 17-35.

Kaźmierczak, J., T. Fenchel, M. Kühl, S. Kempe, B. Kremer, B. Łącka, and K. Małkowski. 2015. $\mathrm{CaCO}_{3}$ precipitation in multilayered cyanobacterial mats: Clues to explain the alternation of micrite and sparite layers in calcareous stromatolites. Life 5 (1): 744-769.

Kendall, C.G.S.C., and W. Schlager. 1981. Carbonates and relative changes in sea level. Marine Geology 44 (1-2): 181-212.

Krumbein, W.E., and Y. Cohen. 1977. Primary production, mat formation and Lithification: Contribution of oxygenic and facultative Anoxygenic cyanobacteria, 37-56. Berlin: Springer-Verlag.

Li, F., J.X. Yan, T. Algeo, and X. Wu. 2013. Paleoceanographic conditions following the end-Permian mass extinction recorded by giant ooids (Moyang, South China). Global and Planetary Change 105: 102-120.

Li, F., J.X. Yan, R.V. Burne, Z.Q. Chen, T.J. Algeo, W. Zhang, L. Tian, Y.L. Gan, K. Liu, and S.C. Xie. 2017. Paleo-seawater REE compositions and microbial signatures preserved in laminae of lower Triassic ooids. Palaeogeography, Palaeoclimatology, Palaeoecology 486: 96-107.

Li, X.Z., S.R. Guan, Q.B. Xie, and Z.C. Wang. 2000. The oncoids genesis in the middle member of the Guanzhuang formation of Eocene in Pingyi Basin. Acta Petrologica Sinica 16 (2): 261-268 (in Chinese with English abstract).

Logan, B.W., R. Rezak, and R.N. Ginsburg. 1964. Classification and environmental significance of algal stromatolites. The Journal of Geology 72 (1): 68-83.

Ma, Y.S., M.X. Mei, R.X. Zhou, and W. Yang. 2017. Forming patterns for the oolitic bank within the sequence-stratigraphic framework: An example from the Cambrian series 3 at the Xiaweidian section in the western suburb of Beijing. Acta Petrologica Sinica 33 (4): 1021-1036 (in Chinese with English abstract)

Meng, X.H., M. Ge, and M.E. Tucker. 1997. Sequence stratigraphy, sea-level changes and depositional systems in the Cambro-Ordovician of the North China carbonate platform. Sedimentary Geology 114 (1-4): 189-222.

Peng, S., L.E. Babcock, and R.A. Cooper. 2012. The Cambrian period. In A Geologic Time Scale 2012, ed. F.M. Gradstein, J.G. Ogg, M. Schmitz, and G. Ogg, 437-488. Boston: Elsevier.

Perry, C.T. 1999. Biofilm-related calcification, sediment trapping and constructive micrite envelopes: A criterion for the recognition of ancient grass-bed environments? Sedimentology 46 (1): 33-45.

Peryt, T.M. 1983. Classification of coated grains. In Coated grains, ed. T.M. Peryt, 3-6. New York: Springer-Verlag.

Pratt, B.R. 2001. Calcification of cyanobacterial filaments: Girvanella and the origin of lower Paleozoic lime mud. Geology 29 (9): 763-766.

Qi, Y.A., S. Chai, X.Y. Zhang, M.Y. Dai, and M. Wang. 2016. Oncoids and their depositional features from the second member of Mantou formation (Cambrian series 3), Weihui area, Henan Province. China Science Paper 11 (21): 2416-2421 (in Chinese with English abstract).

Reolid, M., and L.M. Nieto. 2010. Jurassic Fe-Mn macro-oncoids from pelagic swells of the external Subbetic (Spain): Evidences of microbial origin. Geologica Acta 8 (2): 151-168.

Riding, R. 1991. Classification of microbial carbonates. In Calcareous algae and Stromatolites, ed. R. Riding, 21-51. Berlin: Springer-Verlag.

Riding, R. 2011. Calcified cyanobacteria. In J. Reitner, ed. V. Thiel, 211-223. Encyclopedia of Geobiology. Encyclopedia of Earth Science Series. Heidelberg: Springer-Verlag.

Schaefer, M.O., J. Gutzmer, and N.J. Beukes. 2001. Late Paleoproterozoic Mnrich oncoids: Earliest evidence for microbially mediated $\mathrm{Mn}$ precipitation. Geology 29 (9): 835-838. 
Shapiro, R.S., H.C. Fricke, and K. Fox. 2009. Dinosaur-bearing oncoids from ephemeral lakes of the lower cretaceous Cedar Mountain formation, Utah. Palaios 24 (1): 51-58.

Shi, G.R., and Z.Q. Chen. 2006. Lower Permian oncolites from South China: Implications for equatorial sea-level responses to late Palaeozoic Gondwanan glaciation. Journal of Asian Earth Sciences 26 (3-4): 424-436.

Tucker, M.E., and V.P. Wright. 1990. Carbonate Sedimentology, 1-482. Oxford: Wiley-Blackwell.

Védrine, S. 2008. Co-occurrence of the foraminifer Mohlerina basiliensis with Bacinella-Lithocodium oncoids: Palaeoenvironmental and palaeoecological implications (late Oxfordian, Swiss Jura). Journal of Micropalaeontology 27 (1): 35-44.

Védrine, S., A. Strasser, and W. Hug. 2007. Oncoid growth and distribution controlled by sea-level fluctuations and climate (late Oxfordian, Swiss Jura Mountains). Facies 53 (4): 535-552.

Wang, H., and E.Z. Xiao. 2018. Oncolites in the Zhangxia formation of Cambrian series 3 at Diaoquan section in Lingqiu, Shanxi. Journal of Northeast Petroleum University 42 (5): 44-53 (in Chinese with English abstract).

Wilmeth, D.T., F.A. Corsetti, N. Bisenic, S.Q. Dornbos, T. Oji, and S. Gonchigdorj. 2015. Punctuated growth of microbial cones within early Cambrian oncoids, Bayan Gol formation, western Mongolia. Palaios 30 (12): 836-845.

Xiao, E.Z., K. Latif, M. Riaz, Y.L. Qin, and H. Wang. 2018. Calcified microorganisms bloom in Furongian of the North China platform: Evidence from Microbialitic-bioherm in Qijiayu section, Hebei. Open Geosciences 10: 250-260

Xiao, E.Z., Y.L. Qin, M. Riaz, K. Latif, L. Yao, and H. Wang. 2017b. Sequence stratigraphy division of Cambrian in the northeast area of Lvliang Mountain: A case study of the Cangerhui section in Wenshui City. Journal of Northeast Petroleum University 41 (5): 43-53 (in Chinese with English abstract).

Xiao, E.Z., M.Y. Sui, K. Latif, and M. Riaz. 2017c. Study advances and existed problem for the forming mechanism of the microbial dolomite. Petroleum Geology and Oilfield Development in Daging 36 (2): 26-32 (in Chinese with English abstract).

Xiao, E.Z., M.Y. Sui, Y.L. Qin, K. Latif, M. Riaz, and H. Wang. 2017. Cambrian sequence stratigraphic division for Qijiayu section in Hebei Laiyuan. Petroleum Geology and Oilfield Development in Daqing 36 (6): 16-25 (in Chinese with English abstract).Xiao, E.Z., H. Wang, Y.L. Qin, K. Latif, and M. Riaz. 2019a. Sedimentary fabrics and environmental characteristics of leiolite in Cambrian: A case study from the Changshan Formation in Laiyuan City, Hebei Province. Acta Sedimentologica Sinica. https://doi. org/https://doi.org/10.14027/j.issn.1000-0550.2019.025 (in Chinese with English abstract)

Xiao, E.Z., T. Zafar, K. Latif, M. Riaz, and Y.B. Lu. 2019b. Geochemical and petrographic analyses of the Cambrian oncoids of the North China Platform: Implications for their paleogeography and paleoenvironment. Arabian Journal for Science and Engineering. https://doi.org/https://doi. org/10.1007/s13369-019-04146-5.

Yang, R.C., A.P. Fan, Z.Z. Han, and N.J. Chi. 2011. Status and Prospect of studies on Oncoid. Advances in Earth Science 26 (5): 465-474 (in Chinese with English abstract).

Yang, Y.F., J.H. Zhong, S.Q. Zeng, Z.P. Chen, Q.S. Ji, G. Liang, P. Zhang, and B. Y. Gao. 2009. Characteristics of oncolites in the early cretaceous Qingshankou formation, Songliao Basin and its environmental significance. Acta Sedimentologica Sinica 83 (4): 558-569 (in Chinese with English abstract).

Yu, F., X.G. Fu, G. Xu, Z.W. Wang, W.B. Chen, S.Q. Zeng, C.Y. Song, X.L. Feng, Y.L. Wan, and X.R. Li. 2019. Geochemical, palynological and organic matter characteristics of the upper Triassic Bagong formation from the north Qiangtang Basin, Tibetan plateau. Palaeogeography, Palaeoclimatology, Palaeoecology 515: 23-33.

Zeng, Y.F., J.Q. Zhang, W.Q. Lin, and Y.P. Ye. 1983. Types and environmental significance of oncoids from Yongxian formation of the upper Devonian in siding, Guangxi. Acta Sedimentologica Sinica 1 (1): $42-49$ (in Chinese with English abstract).

Zhang, K.M., W.H. Huang, J.H. Wang, T.T. Zeng, and X.P. Tang. 2013. Characteristics and environmental significance of lacustrine oncolites in Paleogene Guanzhuang formation in Pingyi Basin, Shandong province in eastern China. Acta Sedimentologica Sinica 31 (2): 259-268 (in Chinese with English abstract).

Zhang, W.H., X.Y. Shi, D.J. Tang, and G.Q. Jiang. 2014a. Oncolites from lower-middle Cambrian transition of the western North China platform: A study of their ultra-fabrics and biomineralization. Geoscience 28 (1): 115 (in Chinese with English abstract).

Zhang, W.H., X.Y. Shi, D.J. Tang, and X.Q. Wang. 2014b. Mass-occurrence of oncoids in the early-middle Cambrian transition at western margin of North China platform: A response of microbial community to shallow marine anoxia. Journal of Palaeography (Chinese Edition) 16 (3): 305-318 (in Chinese with English abstract).

Zhang, X.Y., Y.A. Qi, M.Y. Dai, and S. Chai. 2015. Coupling variation of oncoids and trace fossils in the Zhangxia formation (Cambrian series 3), Dengfeng, western Henan Province. Acta Micropalaeontologica Sinica 32 (2): 184-193 (in Chinese with English abstract).

Zhou, G., R.C. Zheng, G. Zhao, H.G. Wen, and L.B. Wen. 2017. Characteristics, origin and geological significance of oncolites of Givetian (middle Devonian) in Ganxi area, northwestern Sichuan. Journal of Jilin University (Earth Science Edition) 47 (2): 405-417 (in Chinese with English abstract).

\section{Publisher's Note}

Springer Nature remains neutral with regard to jurisdictional claims in published maps and institutional affiliations.

\section{Submit your manuscript to a SpringerOpen ${ }^{\circ}$ journal and benefit from:}

- Convenient online submission

- Rigorous peer review

- Open access: articles freely available online

- High visibility within the field

- Retaining the copyright to your article

Submit your next manuscript at $\boldsymbol{\nabla}$ springeropen.com 